\title{
A Decline in the Social Status of the Working Class? Conflicting Evidence for 8 Western Countries, 1987-20I7
}

Comparative Political Studies

202I, Vol. 0(0) I-28

(C) The Author(s) 2021

Article reuse guidelines:

sagepub.com/journals-permissions

DOI: 10.1 | 77/00104|4021 1047400

journals.sagepub.com/home/cps

\section{@SAGE}

\section{Daniel Oesch $^{1,2}$ and Nathalie Vigna ${ }^{1,2}$}

\begin{abstract}
The consensus view among political scientists is that the subjective social status of low-skilled workers has declined over the last decades, and this status loss of the working class is seen as contributing to the rise of the radical right. We examine the micro-foundation of this claim by tracing the evolution of subjective status for different social classes in Europe and the US. We use all available survey rounds of the International Social Survey Programme 19872017 and replicate findings with the European Social Survey 2002-20I6. While unskilled workers perceive their status to be lower than members of the middle class everywhere, we find no relative or absolute fall in their subjective social status over time. Unskilled workers were at the bottom of the status hierarchy in the 1990s and 2010s. Our findings throw doubt on the narrative that sees workers' falling subjective social status as a prominent driver behind the rise of the radical right.
\end{abstract}

\footnotetext{
'Life Course and Inequality Research Centre LINES, University of Lausanne, Lausanne, Switzerland

${ }^{2}$ Swiss National Centre of Competence in Research LIVES, University of Lausanne, Lausanne, Switzerland

\section{Corresponding Author:}

Daniel Oesch, Life Course and Inequality Research Centre (LINES), University of Lausanne, Lausanne 1015, Switzerland.

Email: daniel.oesch@unil.ch
} 


\section{Keywords}

subjective status, social class, social inequality, International Social Survey Programme, working class

\section{Introduction}

An influential argument maintains that, over the last few decades, economic and cultural shifts have depressed the subjective social status of low-skilled workers. This loss of subjective social status among the working class is widely seen as contributing to the mounting support for the radical right (Gidron and Hall, 2017, 2019; Rydgren, 2013). Standing in line for economic prosperity that no longer materializes, low-skilled workers increasingly feel like strangers in their own land (Hochschild, 2016). The radical right is not alone in being depicted as owing its success to voters who feel threatened in their social status: Brexit has also been interpreted as the revolt of lowereducated blue-collar workers who feel left behind (Chan et al., 2020; Hobolt, 2016).

This paper does not add another explanation for right-wing populism, nor does it look into the drivers of party support. Instead, it examines the microfoundations of the claim that the subjective social status of the working class has fallen - in absolute or relative terms - over the last 30 years in Europe and the United States. While accounts of working-class marginalization abound, empirical studies into how subjective social status has evolved over time are exceedingly rare (for an exception, see Gidron \& Hall, 2017). This lack of evidence is surprising because workers' loss of subjective social status seems to be largely taken for granted.

However, it is not obvious that the working class enjoyed a better social standing a few decades ago. The retrospective construction of a better world that was lost is part of the radical right's narrative (Taggart, 2002). Yet, it is ahistorical and may well be wrong. If low-skilled workers were already at the bottom of the status hierarchy in the 1980s, the possibility of a further drop may be limited. Sharp shifts in workers' subjective social status also run counter to the reference group theory which expects individuals to primarily compare themselves to people similar to them, notably family, friends and coworkers (Evans et al., 1992; Merton \& Kitt, 1950). Therefore, if members of the same network experienced similar shifts in their economic fortune, their subjective social status may not have changed much over time.

Of course, there are also compelling reasons to expect a widening class gap in subjective social status over the last three decades. In Europe and the United States, the 1980s represent a watershed moment, when income inequality had reached its lowest level of the 20th century and the Keynesian class compromise came to an end (Piketty, 2019, p. 37). Thereafter, Reagan and 
Thatcher's neo-conservative revolution, the implosion of the communist bloc, automation and globalization put the working class under growing pressure. While top incomes have soared, the bottom half of the population has since been treading water in many countries (Nolan \& Thewissen, 2018; Piketty, 2013).

An open question is whose subjective social status has fallen most. As job growth over the last decades has been skewed towards high-paid and low-paid occupations in some countries (Dwyer \& Wright, 2019; Goos \& Manning, 2007), status anxiety may not be strongest in the bottom tier of society. Rather, it may be skilled workers and the 'squeezed middle' who face the most pressure from technological change and suffer disproportionately from status anxiety (Gidron \& Hall, 2017, p. 66; Kurer \& Palier, 2019).

What happened to the class gap in subjective social status is, then, an empirical question. Our paper examines how it changed for different classes between 1987 and 2017. Over this period, the economic fortune of workingclass households varied widely across Western countries. Median household income evolved more favourably in Britain than the United States, in Norway than in Sweden, in Poland than in Hungary or in Switzerland than in Germany (Nolan \& Thewissen, 2018, 2020). These differences plead for a comparative approach. We thus present a comprehensive analysis of how the class gap in subjective social status evolved in these eight countries over the last 30 years. We do so by analysing individual-level data from the International Social Survey Programme 1987-2017 and the European Social Survey 2002-2016.

In what follows, our paper first clarifies the concepts of class and status. It then discusses the arguments pleading for or against an increase in workers' social standing. Thereafter, it develops three hypotheses about whose subjective social status may have declined over the last decades in which countries. The ensuing sections present the data, method and measurement, and then show results for the absolute and relative evolution of subjective social status over time by class and education. The conclusion discusses the implications of our findings for the burgeoning literature on the radical right.

\section{Class, Status and Nostalgic Bias}

Social status was famously distinguished from social class by MaxWeber (1922). Although the two indicators of social advantage are correlated, they capture distinctive features of stratification. While class arises from the social relations of labour markets and has an objective economic basis, social status is rooted in a symbolic hierarchy and based on subjective perceptions that people occupy more or less honourable positions in society (Chan \& Goldthorpe, 2004). Class thus refers to economic resources and power, whereas status is based on cultural beliefs about honour, esteem and respect (Weber 2005 [1922], p. 683). Status captures the extent of esteem that people 
believe is accorded them within society. It reflects people's views about the recognition they receive relative to others and thus embodies their sense of where they stand in society (Gidron \& Hall, 2017, p. 61). Status matters because many people care as much about social recognition as they do about money and power (Ridgeway, 2014, p. 3).

The issue at stake is whether class differences in subjective social status have widened over the last decades - the period of the Great Divide in economic fortunes (Stiglitz, 2015) - and notably whether the working class has fallen down the status ladder. In the public debate, working-class decline is an ever-present concern. Under the title 'Insecurity forever, the rise of a new class', the New York Times described the 'anxious class' that loses ground in 'an increasingly competitive economy that no longer values workers as much as it once did'. However, this article appeared in 1994 - and thus over a quarter of a century ago, years before the radical right would become a major political force.

This argument raises the possibility that the subjective social status of the working class may have been stable over the last decades for the simple reason that it was very low to begin with (Ganzeboom \& Treiman, 1996, p. 214). It contrasts with the belief that everything was better in the good old days - a belief that is deeply rooted in society. ${ }^{1}$ The romanticized recall of an ideal world that has been lost is particularly important for right-wing populism. By evoking nostalgia, this narrative plots the pure past against the corrupt present and blames the elite for the perceived decline in today's society (Betz \& Johnson, 2004; Taggart, 2002). ${ }^{2}$

Survey evidence suggests that this narrative falls on fertile ground. Gest and colleagues (2018) show that the feeling of nostalgic deprivation - the gap between individuals' perceived current and past status - increases radicalright support in Britain and the United States. In the same vein, Britons who voted for Brexit were much more likely to declare that life is worse today than 30 years ago than Britons who voted against Brexit (Gidron \& Hall 2019, p. 4). Similarly, Elchardus and Spruyt (2016) show for Belgium that support for populism is closely linked with a view of society being in decline. However, one single data point in time does not settle the question as to whether subjective social status really did decline over time - or whether we deal with nostalgic deprivation and thus a retrospective construction.

Besides nostalgic bias, another reason for doubting major shifts in subjective social status comes from reference group theory, which argues that individuals form a judgement about their own social standing by comparing it not to society as a whole, but to people around them such as family, friends and colleagues (Merton \& Kitt, 1950). As networks are homophilous and bring together people in similar occupations who are exposed to similar economic shifts (McPherson et al., 2001), inter-group comparison of subjective social status could well remain constant over time - because people in the same 
network move up (or down) together. In support of reference group theory, Kelley and Evans (1995, p. 166) find for six Western countries that 'rich and poor, well-educated and poorly educated, high-status and low-status, all see themselves near the middle of the subjective status ranking'. The reason is that even high-status people consider many acquaintances to be above them (family doctors looking up to medical school professors) and low-status people see others even lower (factory workers looking down on sweepers) (Evans et al., 1992, p. 465).

\section{Political and Economic Pressure on the Working Class}

Nostalgic bias and reference group theory notwithstanding, there are good reasons to expect the working class to have fallen down the status ladder. From the middle of the 19th century to the 1970s, the central question in European politics revolved around the worker question and the place that the working class should occupy in society (Castel, 1999; Esping-Andersen, 1990). This is no longer the case as the working class has been moved from the centre of the political scene to its margins. ${ }^{3}$

In parallel to political marginalization, economic developments over the past 30 years such as mass unemployment, trade union erosion, the spread of atypical jobs and wage stagnation have stalled the gradual improvement of living conditions for the working class (Hall \& Lamont, 2013). The working class has lost out from educational expansion and occupational upgrading and finds itself at the gradually less populated bottom-end of the social structure (Oesch \& Piccitto 2019). The neoliberal turn in the 1980s and 1990s also redefined the criteria of what counts for social status, making individuals' success on the market more central for public esteem (Hall \& Lamont, 2013, p. $4)$. While the prestige of highly educated professionals and managers increased, lower-skilled workers were forced to accept poorly paid jobs - jobs that, at the same time, may have provided increasingly weak social status.

These changes in politics and the economy are also seen as having fostered a feeling of relative deprivation, where growing segments of the working class believe that they receive less than what they deserve, both in terms of material resources and social recognition (Elchardus \& Spruyt, 2016; Hall \& Lamont, 2013). Pushed to the fringes of the national community, the social integration of the working class may thus have become tenuous (Castel, 1999; Gest, 2016; Gidron \& Hall, 2019).

\section{Whose Subjective Status has Declined?}

The argument of status anxiety comes in several versions. An influential version is associated with Gidron and Hall (2017, p. 63) who argue that economic and cultural developments in Western democracies have combined 
over the past 30 years to depress the subjective social status of lower-skilled workers in manual, clerical and routine service occupations. The fall in subjective social status is expected to be particularly strong among white working-class men, whose rank in the status-order has been additionally challenged by women's and ethnic minorities' quest for equal rights. Women and minorities are seen as 'cutting in line' ahead of working-class men in the long wait for economic progress (Hochschild, 2016). While Gidron and Hall (2017, p. 63) put forward occupation and social class as the decisive locus of falling subjective social status, ${ }^{4}$ their empirical analysis looks at how the social status of men and women without college education has evolved over time relative to that of all men and women. Their findings tentatively suggest that the subjective social status of lower-educated men has decreased in most Western countries, but results are descriptive, based on a few survey rounds only, and do not easily extrapolate to the entire working class. Still, our first hypothesis is that Gidron and Hall's (2017) argument about working-class decline holds.

Hypothesis 1. Over the last 30 years, the subjective social status of the lowskilled working class has declined both in absolute terms and relative to that of the (upper-) middle class.

A second version of the status-anxiety argument sees social stratification in terms of three tiers. Its starting point is that job growth over the last decades has been skewed towards high-paid and low-paid occupations at the expense of mid-paid occupations, notably in the US (Dwyer \& Wright, 2019; Wright \& Dwyer, 2003) and UK (Goos \& Manning, 2007; Oesch \& Piccitto, 2019). The idea is that intermediate jobs held by skilled production workers and office clerks - the skilled working class - are more exposed to automation and offshoring than low-paid service jobs. Therefore, rather than the bottom tier of society, it may be the mid-tier whose subjective social status has come under greatest pressure. These workers who are a few rungs up from the bottom of the social hierarchy may suffer most from status anxiety because 'they still have a significant measure of status to defend' (Gidron \& Hall, 2017, p. 66). A telling example comes from an ethnographic study of bus drivers in France whose social representation is not bipolar, but tripolar, distinguishing three hierarchical levels: the top, middle and bottom. As bus drivers, they see themselves in the middle and feel under pressure not only from above, but also from below, notably from migrant workers and the unemployed (Schwartz, 2009, p. 5).

This argument fits the narrative of the 'devalued' intermediate classes in the United States who perceive the elites from above and the minorities from below to be thriving at their expense (Hochschild, 2016). Moreover, it echoes findings that the strongest supporters of the radical right are not the most deprived individuals, but production workers who are skilled (Bornschier \& 
Kriesi, 2012, p. 21) and who perceive their economic situation as middling (Im et al., 2019). Radical-right support has thus been explained by a relative decline of status and position in the income distribution (Bornschier \& Kriesi, 2012, p. 21; Burgoon et al., 2018). Likewise, Brexit has been seen as an expression of "the social malaise of intermediate classes, the so-called "squeezed middle"" (Antonucci et al., 2017, p. 2). This leads us to formulate a second hypothesis:

Hypothesis 2. Over the last 30 years, it is primarily the subjective social status of the skilled working class that has declined both in absolute terms and relative to that of the upper-middle class.

\section{Country Differences in the Evolution of Status}

Our discussion suggests that workers' subjective social status has evolved uniformly across the Western world. This assumption is not implausible if global shifts such as skill-biased technological change and offshoring put pressure on the working class everywhere. At the same time, national institutions such as the welfare state and macroeconomic policy, collective bargaining and minimum wages are likely to channel these shifts into different outcomes for working-class households in different countries (Gautié \& Schmitt, 2010).

Our empirical analysis thus compares the evolution of subjective social status for eight countries. We select four pairs of countries that each share a range of cultural and geographic features, but diverge in the economic trajectory of the working class since the 1980s. These pairs comprise Britain and the United States, Germany and Switzerland, Hungary and Poland, and Norway and Sweden. One could imagine additional - and different - pairs, but our selection is limited because long data series on subjective social status are available for only a dozen countries.

While these eight countries were exposed to similar shifts in technology and trade, the working class fared much better in some countries than in others. This becomes clear from Figure 1 which shows the share of national income that went to the bottom half of the adult population between 1985 and 2015. While this share remained stable at 22 per cent in the UK, it dwindled from 18 to 13 per cent in the United States. Similarly, it stayed constant at 27 per cent in Switzerland, but shrank from 27 to 21 per cent in Germany. Households in the bottom half did somewhat better in Norway (where their income share went from 30 to 29 per cent) than in Sweden (where their share declined from 31 to 27 percent), but these changes are minor. In contrast, the proportion of income going to the population's bottom half fell dramatically in the former socialist countries, with a larger relative decline in Hungary (from 45 to 29 per cent) than Poland (from 31 to 24 per cent). 


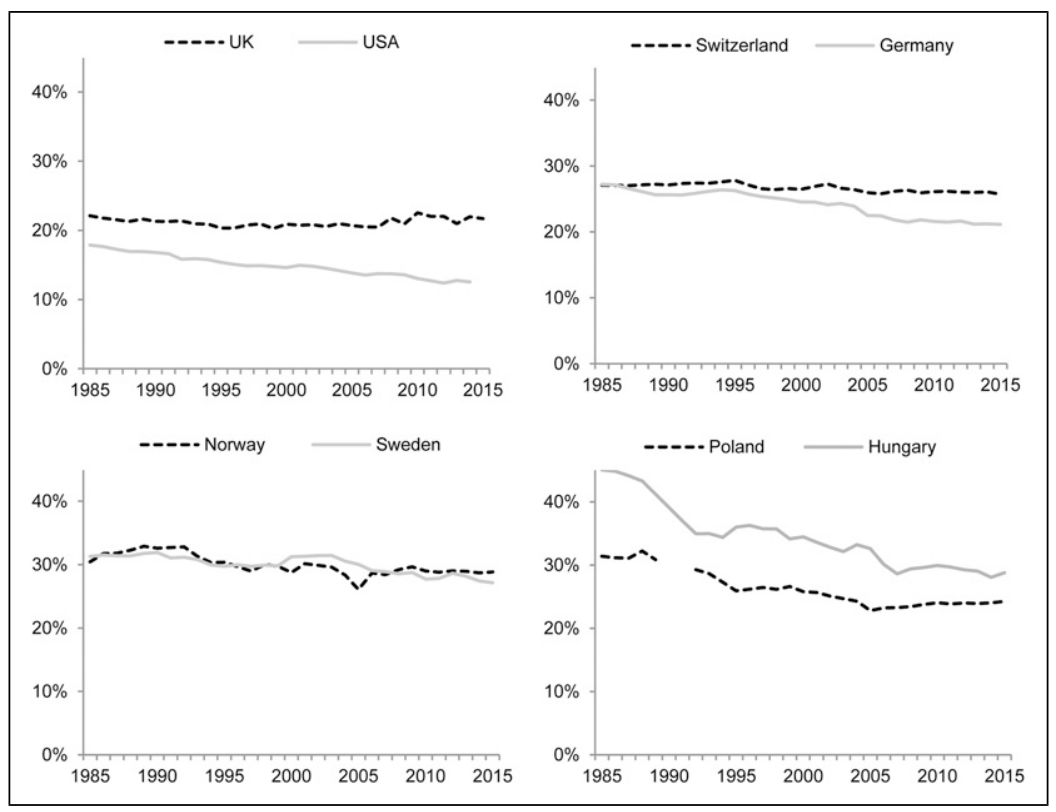

Figure I. Share of pre-tax national income that goes to the bottom $50 \%$ of the adult population.

The working class did not only fare better in relative terms in some countries than in others, but also in absolute terms. The evolution of median household income, corrected for inflation, gives a good idea of how living conditions evolved for ordinary people over time. In the United States, the median household saw its income increase, on average and in constant prices, by a meagre 0.3 per cent per year between 1979 and 2013 as compared to an annual rise of 1.6 per cent in the UK over the same period (Nolan \& Thewissen, 2018). Similarly, the median household in Hungary lost 0.2 per cent per year (1991-2012), whereas it gained 1.4 per cent in Poland (1992-2013). In both Norway and Sweden, median households saw their income rise substantially, although annual income growth was stronger in Norway (2.4 per cent over 1979-2010) than Sweden (1.8 per cent over 19832013). Finally, the median household's income evolved almost as sluggishly in Germany as in the US, with an annual increase of 0.5 per cent between 1984 and 2010, half as much as in Switzerland (Nolan \& Thewissen, 2018, 2020).

The stagnation of household income in Germany, Hungary or the US is likely to contrast with social expectations. Children raised in the three postwar decades were socialized in a period of steadily increasing incomes, with each new generation expecting to exceed the level of economic prosperity 
enjoyed by the previous generation (Inglehart \& Norris, 2017, p. 449; Gest et al., 2018, p. 1698). This seems no longer to be the case for many workers in the Western World, notably the United States (Chetty et al., 2017). Based on the evolution of relative income shares and absolute income over the last three decades, we formulate a third and last hypothesis that expects country differences:

Hypothesis 3. Over the last 30 years, the subjective social status of the working class should have fallen more in the US than the UK, in Germany than Switzerland, in Hungary than Poland and, possibly, in Sweden than Norway.

\section{Data, Measures and Method}

\section{Data}

Our empirical analysis is based on individual-level data from the International Social Survey Programme (ISSP). ${ }^{5}$ The ISSP is an academically driven crosscountry collaboration that produces nationally representative surveys. While the ISSP includes more than 40 countries, it was founded in 1984 by just four countries and long-term data availability is limited to only a dozen countries. Therefore, our analysis focuses on the eight countries mentioned. However, in order to show that countries were not cherry-picked based on results, our robustness tests present findings for a larger group of nations for which long data series are available. ${ }^{6}$

The question on subjective social status was included in the ISSP rounds 1987, 1992, 1999 and then between 2002 and 2017 annually (Norway and Sweden), biannually (Germany, Hungary and Switzerland) or less frequently (Poland, the UK and US). Our analysis attributes each ISSP round to the year when the survey was effectively fielded rather than the official year of a module. This provides us with a maximum of 18 (Sweden), 17 (Norway), 15 (Hungary) and 12 (Germany) yearly data rounds and a minimum of 5 (UK), 9 (Poland and the US) and 10 (Switzerland) yearly data rounds. We restrict our analysis to the working-age population from 20 to 60 and leave away individuals with incomplete information. This provides us with analytical samples of a minimum of 500 respondents in Britain (1999) and a maximum of 3223 respondents in Poland (1987). ISSP only provides weights for some years and some countries (e.g. none for Sweden). We thus show unweighted results, but our findings remain unchanged when using weights (results available from the authors). Supplementary Table A1 in the appendix shows the data availability and number of observations for each country and survey year. 


\section{Measures}

Our key dependent variable is subjective social status which we measure with a single-item measure that captures an individual's perceived rank in the social hierarchy. It asks individuals to place themselves on a 10-point social ladder. The question states that in our society there are groups which tend to be towards the top and groups which tend to be towards the bottom'. Respondents are then shown a vertical figure going from 1 to 10 and are asked 'where would you put yourself on [such] a scale from the bottom to the top?' This question has been widely used in recent research on subjective social status (e.g. Lindemann \& Sarr, 2014; Gidron \& Hall, 2017; van Noord et al., 2019). It has, however, a colourful past. The pioneers of the ISSP had originally considered it as a measure of subjective class identification (Kelley \& Evans, 1995; Smith, 1986), before calling it subjective social status in later studies (Evans \& Kelley, 2004). In the early 2000s, a group of health psychologists had then re-invented the same question as the MacArthur scale of subjective social status (Adler et al., 2000; Singh-Manoux et al., 2003).

Of course, this single-item indicator of subjective social status is not beyond criticism. Asking individuals to locate themselves on a hierarchical status ladder is just one way of measuring social status. Another indicator measures Max Weber's notion of status as social honour by looking at marital and friendship networks. The argument is that individuals feel comfortable mingling with and marrying into networks of people who are neither too much above nor below their status rank. Social status is then defined in terms of social distance and measured by patterns of friendship or marriage between individuals working in different occupations (Carella \& Ford, 2020; Chan \& Goldthorpe, 2004).

While our analysis follows Gidron and Hall (2017) and focuses on the subjective status ladder, we resort to two additional items as a robustness test. A first item asks respondents to compare their job's social status with the status of their fathers' job when respondents were in their teens (on a five-point scale). ${ }^{7}$ This question makes the reference person explicit and tells us how individuals in different classes see their own status relative to their fathers' status when they were teenagers. This question about intergenerational status mobility was only asked in four ISSP rounds (1987, 1992, 1999 and 2009).

A second item asks people to indicate how satisfied they are with their life (on a scale from 0 to 10) and is measured with data from the European Social Survey (ESS). If the falling social status of the working class has gone along with resentment, anger and anxiety, this should also show in a decrease of life satisfaction. Earlier research suggests that subjective social status and life satisfaction are strongly correlated across Europe (Schneider, 2019). ESS 2012 contains both measures and our analysis confirms this finding: The correlation between subjective social status and life satisfaction is 0.44 
(Pearson's R) and an increase by one point on the (11-point) social-status scale leads to an increase by 0.57 points on the (11-point) life-satisfaction scale. Since the question on life satisfaction is not asked in the ISSP, we resort to the eight rounds of the ESS that were carried out between 2002 and 2016. This has the added benefit of allowing us to replicate our analysis for the same countries (except the US) with a different dataset. Supplementary Table W1 in the webappendix shows the descriptive statistics.

Since our measures of subjective social status and life satisfaction use three different scales $(1-10,1-5$ and $0-10)$, we standardize these scales into a common unit of measurement that goes from 0 (minimum status or life satisfaction) to 100 (maximum status or life satisfaction), making for easier comparison of results across models.

Our key independent variable is social class. We follow Gidron and Hall $(2017,2019)$ and resort to a schema proposed by Oesch (2006), distinguishing five classes: (1) the upper-middle class of managers, professionals and large employers; (2) the lower-middle class of associate managers, semiprofessionals and technicians; (3) small business owners including selfemployed artisans, shop owners and farmers; (4) the skilled working class of craftsmen, office clerks, sales and service workers and (5) the unskilled working class of operatives, farmhands and unskilled service workers. This schema has a hierarchical structure and comes close to the classification devised by Erikson and Goldthorpe (1992). As a robustness test, we do not separate the working class hierarchically into skilled and unskilled workers, but instead distinguish production workers, service workers and office clerks. This allows us to test the argument that it was the traditional working class of (industrial) production workers whose subjective social status has declined.

Individuals are allocated to different classes based on information about their current occupation or, where missing, on their partner's occupation (as measured with ISCO 4-digit), ${ }^{8}$ employment status (in order to separate employees from employers and the self-employed) and, for employers, the number of employees they have (to distinguish large employers from small business owners).

We replicate our analysis by using education instead of class as indicator of stratification and distinguish three educational levels: (1) less than full uppersecondary education; (2) upper-secondary and post-secondary, but not tertiary education and (3) tertiary education (i.e. university degree). Besides class and education, our models also control for survey year, age and gender. Supplementary Table A2 in the appendix shows descriptive statistics for all the variables used.

\section{Method}

In order to reduce short-term fluctuations that may be due to common errors in surveys linked to coverage, sampling, nonresponse or measurement, we use 
locally weighted scatterplot smoothing (LOWESS). This technique consists in calculating the subjective social status of each class in a given year by also taking into account information from adjacent years, with neighbouring years getting higher weights and more distant years, lower weights. We then estimate for each country a separate linear regression based on the following equation

$$
y_{i}=\beta_{1}+\beta_{2} \operatorname{class}_{i}+\beta_{3} \text { year }_{i}+\beta_{4} \operatorname{class}_{i} \text { year }_{i}+\beta_{5} \text { controls }_{i}+\epsilon_{i}
$$

Our dependent variable $y_{i}$ measures the subjective social status of individual i. Our two main predictors are individuals' social class and the survey year. The interaction term class $i *$ year $_{i}$ accounts for a differential time trend in subjective social status across classes and thus shows relative change. Controls $s_{i}$ include gender, age and education, and $\epsilon_{i}$ represents the error term. We facilitate the interpretation of results by graphically plotting the predicted values of subjective social status over time for different class profiles. ${ }^{9}$

\section{Descriptive Results for Subjective Social Status Over Time}

Figure 2 shows how the subjective social status of different classes has evolved over time in absolute terms. While these graphs are based on scatterplot smoothing, Supplementary Figure A1 in the appendix shows raw averages for each year and reminds us that the second 15 years under study (2002-2017) are based on more data points than the first 15 years (19872002). The members of the upper-middle class attribute themselves, on average, the highest social standing in each country and year, whereas the members of the unskilled working class perceive themselves everywhere to be towards the bottom of society. At the top, the upper-middle is followed by the lower-middle class. At the bottom, the skilled working class has the secondlowest status. Small business owners occupy an intermediate position.

This rank-order confirms that our measure of status captures hierarchical differences in social standing. Yet, our primary interest is not in levels, but the time trend. In this regard, Figure 2 contradicts our expectations. The subjective social status of the unskilled and skilled working class remained basically constant in Britain, Poland, Sweden and Switzerland. It possibly even increased in Germany (between 2002 and 2015) and the US (between 1987 and 2005). Hungary in the 1990s and Norway after 2005 are the two only countries where the subjective status of the working classes decreased. Supplementary Figure W1 in the web-appendix presents the same analysis for six additional countries (Australia, Austria, Czech Republic, Russia, Slovak 


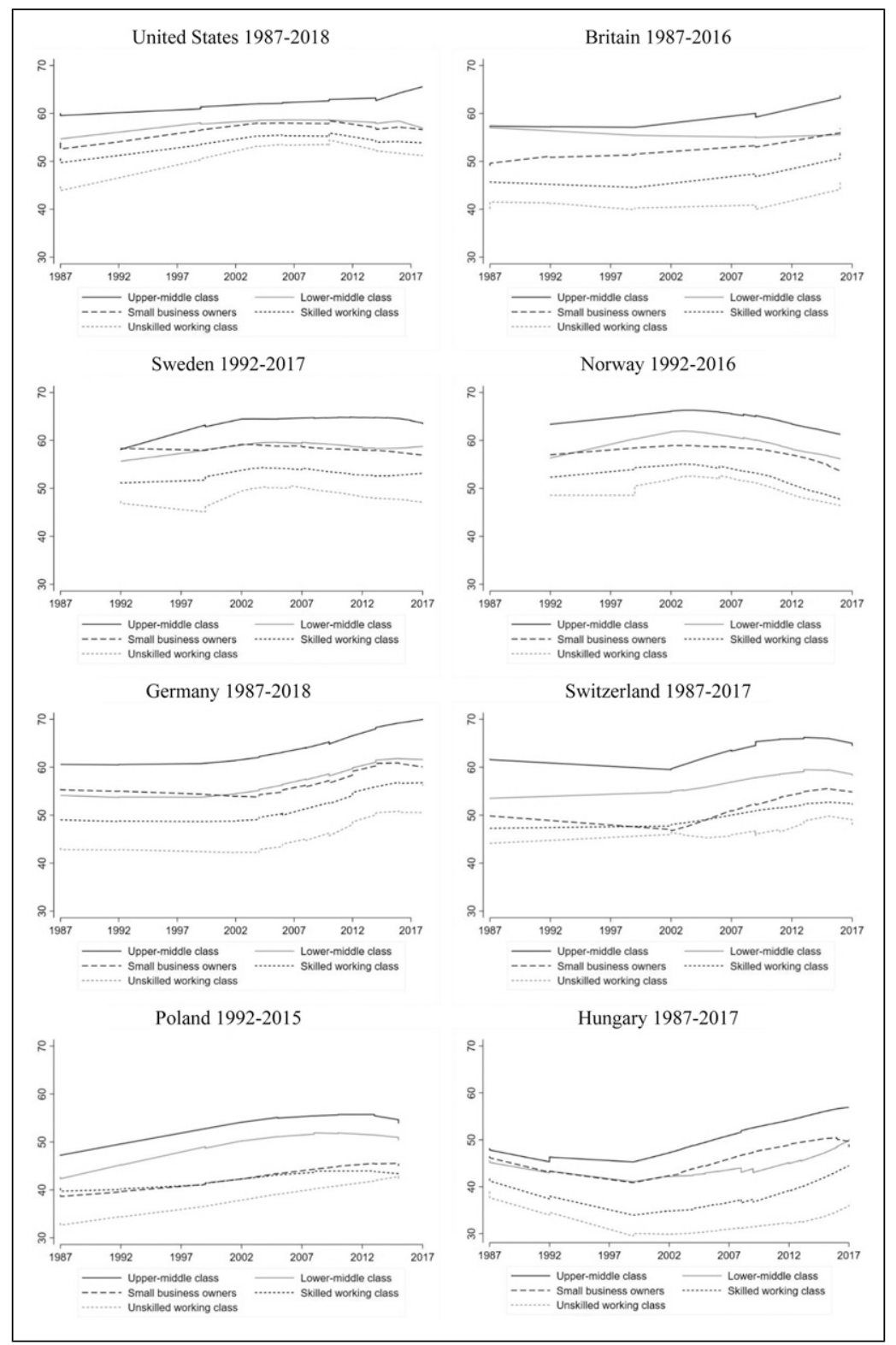

Figure 2. The evolution of subjective social status (on a scale from 0 to 100 ) by social classes. 
Republic and Slovenia) and also points to a stable time trend in the subjective status of the working classes.

The central argument put forward by Gidron and Hall (2017) was the declining status of working-class men rather than women. For this reason, we show the evolution of subjective social status separately for men and women (see Supplementary Figures W2 and W3 in the web-appendix). Yet again, the time trends do not reveal any systematic decline in subjective status among either men or women. While both men and women in more advantaged class positions have higher subjective status than working-class men and women, the class gap in social status remains constant over time for both genders.

Figure 2 only provides crude evidence on the relative change in the subjective social status of the working classes compared to the middle classes. Possibly, subjective status increased faster in the upper-middle class than the working class. We thus specifically present the difference in status of the skilled and unskilled working class relative to the upper-middle class over time, again focusing on the critical category of men. The result is shown in Supplementary Figure A2 (appendix) and confirms that the gap in subjective social status between the upper-middle class and both the skilled and unskilled working class was stable or decreased in almost all the countries, except in Sweden 1992-1999, Poland 1997-1999 and Hungary.

We further compare our results to Gidron and Hall (2017) by replicating our analysis for three educational levels. When tracing the evolution of subjective social status by education, we observe the expected hierarchy with university-educated individuals having everywhere the highest social status and individuals with less than upper-secondary education the lowest status (see Supplementary Figure A3 in the appendix). However, the evolution over time in social status is again flat. The social status of both the low- and mideducated group seems constant over time. Despite some fluctuations, the dominant trend is stability.

\section{Multivariate Results for Subjective Social Status Over Time}

Of course, these bivariate relationships may hide large shifts in classes' composition. This is the case if the mean age of working-class incumbents increased faster than in the other classes, if expanding university attendance changed the educational composition of the middle classes or if women's growing employment changed the gender mix more in one class than another. Therefore, we estimate a multivariate linear model on the evolution of social status by class and education, keeping age and gender constant.

Figure 3 shows how the predicted subjective social status evolved over time for a 40-year-old man from either the upper-middle class with university 


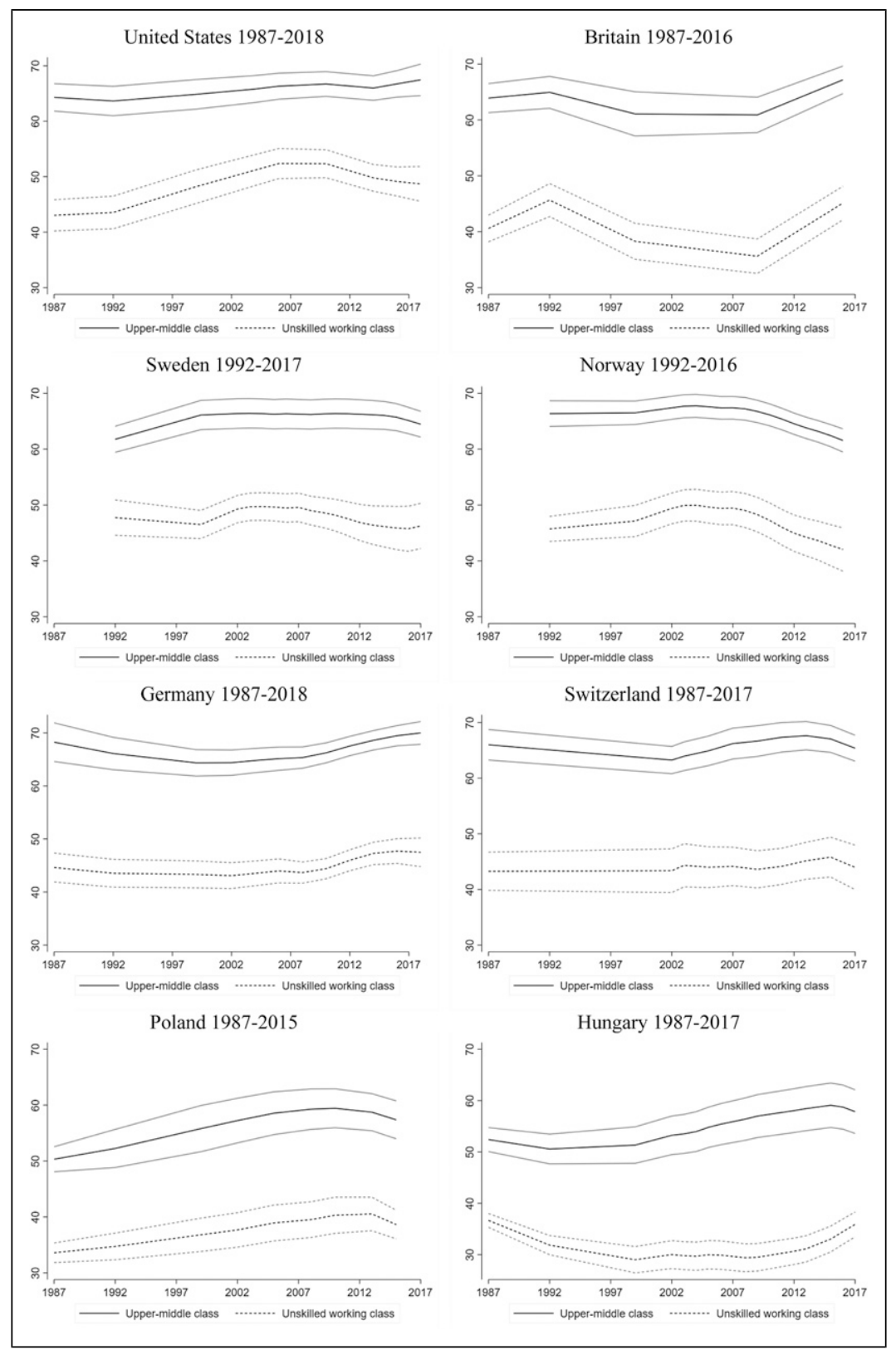

Figure 3. Predicted values and confidence intervals of subjective status (0-100) for a man aged 40 in the upper-middle (with tertiary education) or unskilled working class (without upper-secondary education). 
education or the unskilled working class with compulsory schooling. ${ }^{10}$ When comparing these two profiles that combine the highest class with the highest educational level and the lowest class with the lowest educational level, we observe larger disparities in subjective social status. Still, these estimates contradict the idea of an absolute decrease in the subjective social status of the unskilled working class in six out of eight countries: Germany, Hungary, Sweden, Switzerland, Britain and the US. In the US, their status even seems to have increased. We find a decreasing trend only for Norway (after 2007) and Poland (after 2012).

While these figures throw doubt on our hypothesis of an absolute downward trend in the status of the working class, the status gap may still have widened in relative terms if the subjective social status of the uppermiddle class increased (more) over time. We test this argument by estimating a regression on social status with class, time period and an interaction as predictors (as well as age and gender as controls). The interaction term between class and time period then tells us whether there is a differential trend in social status across classes. As reference period, we take the survey rounds before 2000 and compare them to the subsequent survey rounds which we merge into three 5-year periods (2000-2005, 2006-2011 and 2012-2017).

The coefficients are shown in Supplementary Table A3 (appendix) and suggest that social status evolved in parallel for the unskilled working class and the upper-middle class in Norway, Poland, Sweden, Switzerland and, with the exception of 2006-2011, Germany. In the United States, the unskilled working class made up ground in terms of subjective social status, whereas it clearly fell behind the upper-middle class in Hungary and, to a lesser extent, in Britain. Contrary to our first hypothesis, the gap in social status between the upper-middle and unskilled working class seems not to have widened over time in the majority of countries.

The stability of the class gap is not quite as clear when comparing the evolution of social status between the skilled working class and the uppermiddle class. While the differential is constant in Britain and Switzerland and even decreases in the United States, we observe a widening gap in Poland and, above all, Hungary. To a lesser extent, a relative status decline is also visible for the skilled working class in Germany in the period 20062011 and in Norway and Sweden after 2012. However, except in Hungary and Poland, the effect size reaches at most 2.8 points and is thus small, given that the mean status scores of skilled workers lie between 40 and 50 points (and status differs by 9-12 points between the upper-middle class and skilled working class). Moreover, there is no relative status decline for the skilled working class in the US, but a status increase. Overall, these results provide little support for our second hypothesis. 


\section{Robustness Tests}

\section{Another Measure of the Working Class}

We assess our findings by using a different class measure that does not hierarchically separate the skilled from the unskilled working class, but distinguishes, within the working class, production workers (such as assemblers and craft workers), service workers (such as sales assistants and waiters) and office clerks (such as secretaries and receptionists). The other class categories of small business owners, lower-middle and upper-middle class remain unchanged. This class measure allows us to test the claim that de-industrialization has primarily put pressure on the traditional working class of production workers, whereas interpersonal service workers may have been less affected.

Supplementary Figure W3 compares how the predicted subjective social status evolved over time for a 40 -year-old male production worker or service worker relative to a member of the upper-middle class. We find again that service and production workers attribute themselves a lower status than do members of the upper-middle class. However, there is basically no difference between these two working-class categories in either absolute levels or the evolution over time. Point estimates are very close and confidence intervals overlap. These results invalidate our expectation of a stronger fall in the social status of production workers than service workers.

Another possibility is that the subjective social status of the working class has not declined on average, but has drifted apart internally as parts of the working class benefitted from rising living standards and another part was left behind. We test this idea of increasing heterogeneity within the working class by tracing variance in social status by class over time. Supplementary Figure W4 plots the standard deviation of our status measure for three classes over the last three decades. It shows that variance in social status is systematically higher among unskilled workers than skilled workers and, above all, the upper-middle class. However, with the exception of Norway and Sweden in the 1990s and Switzerland after 2012, we do not observe anywhere an increasing variance in status within the working classes.

\section{Social Status Compared to Father's Social Status}

As a further robustness test, we use a status measure where respondents compare the social status of their present job relative to the perceived status of their father's job when respondents were aged 16 (see footnote 7 for the question wording). For this indicator, Figure 4 reports predicted probabilities from a multivariate regression model and shows how middle-aged men perceive their status in an intergenerational perspective depending on whether they belong to the upper-middle class (with university education) or the unskilled 


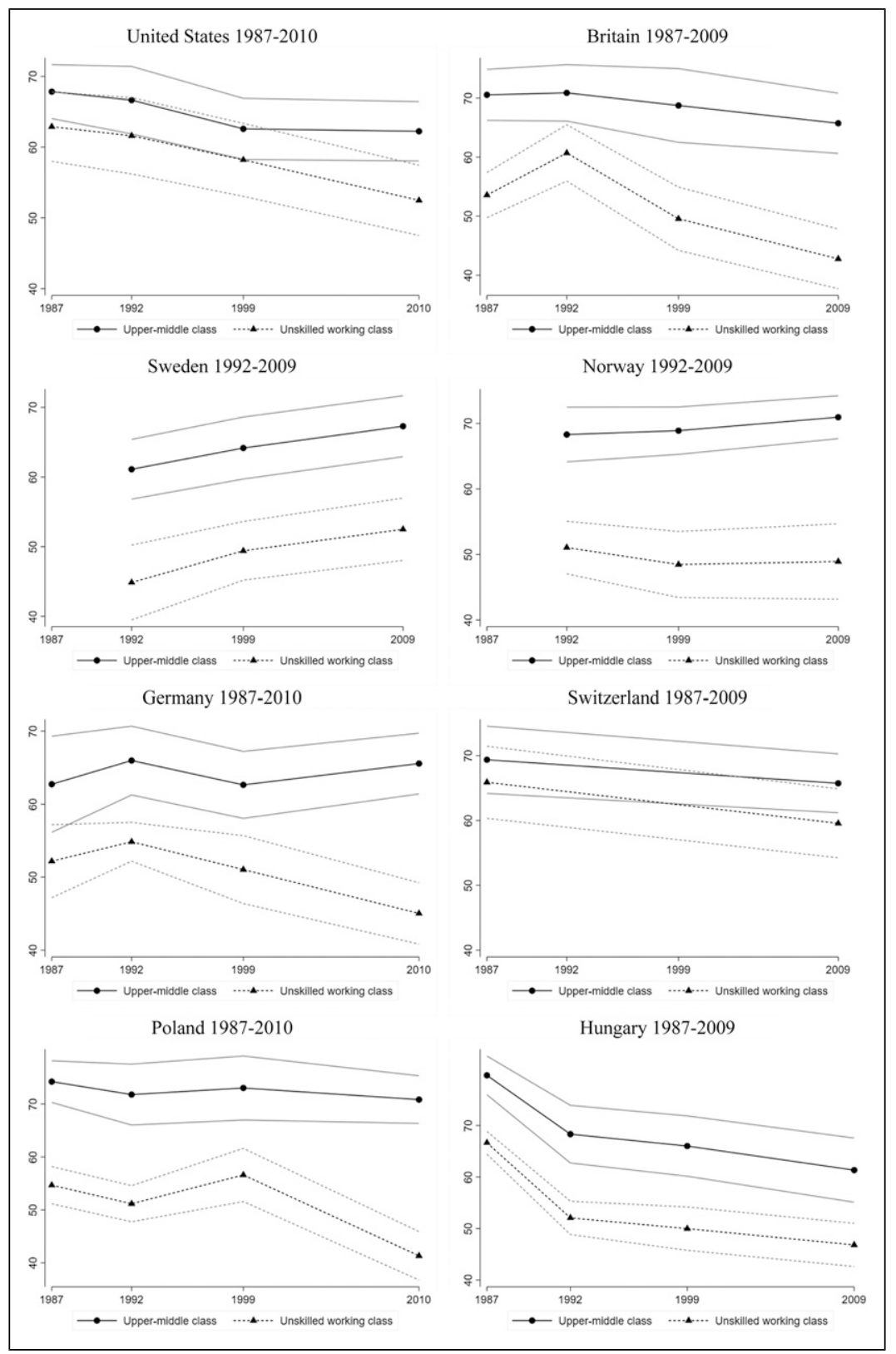

Figure 4. Subjective status of respondent's job as compared to status of father's job for a man aged 40 in the upper-middle (with university education) or unskilled working class (without upper-secondary education). 
working class (without upper-secondary education). Over time, unskilled workers provide a decreasing assessment of their status relative to their fathers in Britain, Germany, Hungary, Switzerland and the US, whereas the status was stable in the 2000s in Norway and Sweden. Overall, in the eyes of the unskilled working class, the status of their own job compared less favourably to the status of their fathers' jobs in 2009 than it did for respondents in the 1990s.

However, since these analyses are available for four survey rounds at most and stop in 2009, they are based on small samples and results are uncertain. We therefore resort to a formal test of period differences by regressing class, survey year and the interaction between class and survey year on intergenerational subjective social status, holding age and gender constant (see Supplementary Table W4 in the web-appendix). Between the early 1990s and 2009, the class gap in intergenerational status is basically constant in Hungary, Sweden, Switzerland and the US, whereas the disparity becomes larger in Britain, Germany, Norway and Poland. This gap tends to widen over time for both the skilled and unskilled working class. Note, however, that these estimates on the evolution of intergenerational social status often fail to reach statistical significance and are thus more tentative than the results for subjective social status.

\section{Life Satisfaction as a Proxy for Discontent}

Some readers may be sceptical about the substantive meaning of our measure of subjective social status. For this reason, we provide a last robustness test by replicating our analysis with a different measure - life satisfaction - and a different dataset - the European Social Survey. Workers who feel left behind and marginalized are likely to not only report lower social status, but also to have become less satisfied with their lives. Both earlier research (Schneider, 2019) and our own analysis indicate that individuals' subjective social status is closely associated with their life satisfaction.

Figure 5 shows how life satisfaction evolved by class over the eight rounds of the European Social Survey that took place between 2002 and 2016. We estimate a multivariate regression on life satisfaction for a man aged 40 who is either in the upper-middle class and holds university education or in the unskilled working class and has less than upper-secondary education. ${ }^{11}$ Results are plotted as predicted values and show that the members of the unskilled working class report systematically lower life satisfaction than those of the upper-middle class in each one of the seven European countries studied. Differences are small (and not statistically significant) in Sweden and Norway, but large in Britain, Germany and Hungary.

However, concerning the evolution over time, we do not observe any downwards trend in life satisfaction among unskilled workers in any country - neither in absolute terms, nor in relative terms as compared to the 


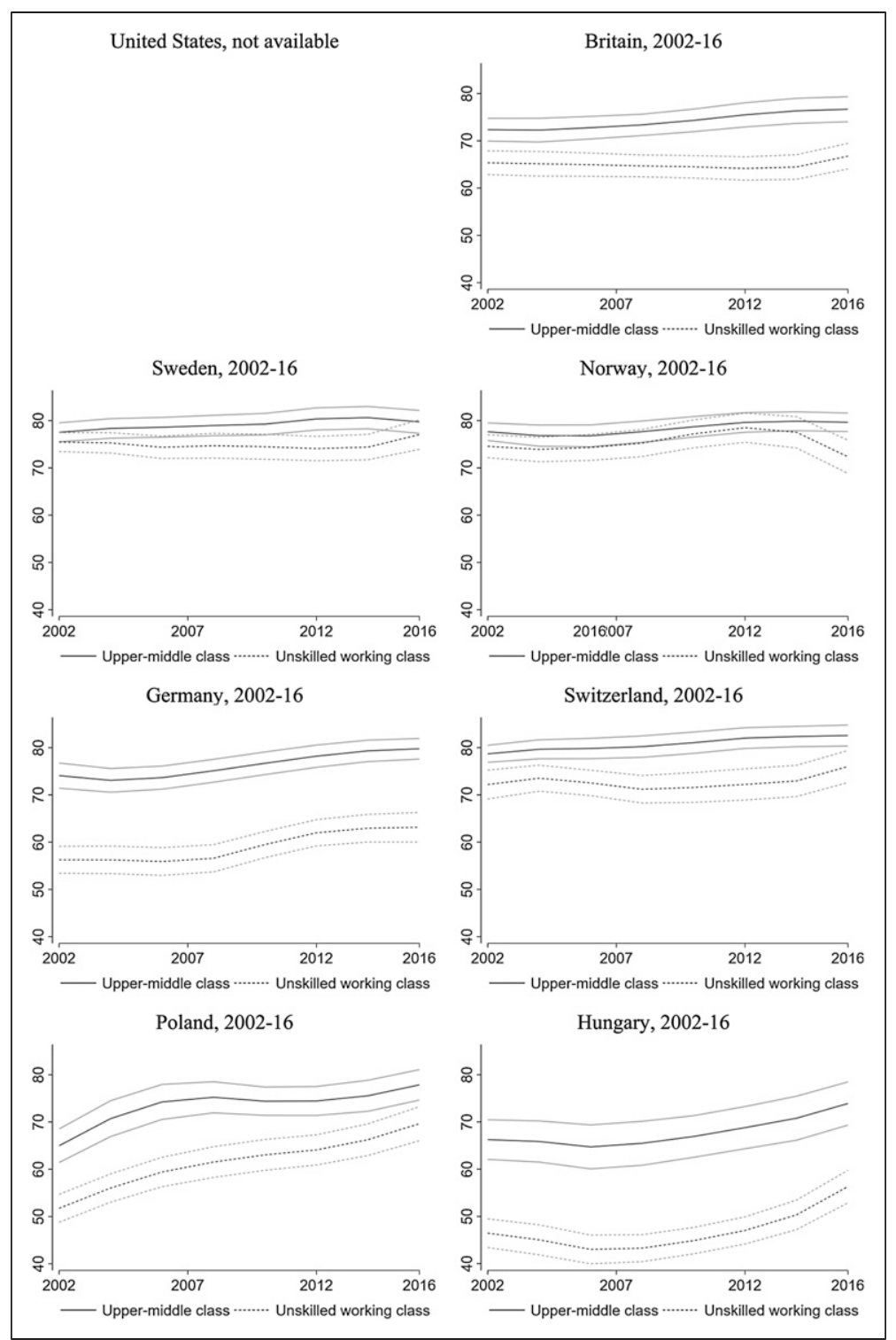

Figure 5. Predicted values of life satisfaction (from 0 to 100) for a man aged 40 in the upper-middle class (with university education) or unskilled working class (without upper-secondary education). 
upper-middle class. Two exceptions are Poland where the unskilled working class makes up ground and Hungary (as well as possibly Britain) where it loses ground relative to the upper-middle class. Elsewhere, the dominant pattern seems stability over time. This pattern is consistent with the trendless fluctuation that we observe for the evolution of subjective social status.

\section{Conclusion}

Objective indicators show that over the last few decades the working class has been left behind in many respects in the Western world. Notably, their real incomes have stagnated (Nolan \& Thewissen, 2018), while top incomes and income inequality have risen sky high (Piketty, 2013). The most tangible sign that the quality of life of the working class has declined comes from mortality rates in the United States, showing that the life expectancy of lowly educated middle-aged whites has been falling since 1999 (Case \& Deaton, 2015).

Our paper's goal has been to examine whether these objective evolutions are reflected in workers' subjective assessment of their place in society. We thus tested the claim that the subjective social status of the working class has fallen over the last 30 years in Europe and the United States. Following Gidron and Hall (2017), we had expected to see a decline in the subjective social status of low-skilled (hypothesis 1) and skilled workers (hypothesis 2) in absolute terms as well as in relative terms when compared to the upper-middle class. Moreover, based on the income evolution of the population's bottom half, we expected a stronger decline in some countries such as Germany, Hungary and notably the United States where income inequality has soared than in Norway, Sweden and Switzerland where income inequality has remained more stable (hypothesis 3 ).

We tested these three hypotheses by analysing all the available rounds of the International Social Survey Programme between 1987 and 2017. Contrary to our expectations, there is no downwards trend in workers' subjective social status and no widening class gap in subjective social status over time. Rather, we find trendless fluctuation and stability in the subjective social status of the unskilled and skilled working class as well as among the lowly educated. These findings prompt us to not only reject our first two hypotheses, but also the third expectation of systematic cross-country differences. The social status of the working class does not seem to have evolved differently in Britain, Germany or the United States than in Norway, Sweden and Switzerland.

The only result that is in line with our expectations stems from the intergenerational status comparison. In 2009, working-class respondents evaluated their status less favourably relative to their fathers' status than working-class respondents had done 20 years earlier. Over time, workers have thus come to perceive less status mobility - either because their own status has fallen or their fathers' status has risen over time (as younger cohorts of fathers 
possibly benefitted from the rapid occupational upgrading of the post-war decades). Yet, as we do not find any evidence for a decreasing trend in workers' life satisfaction over the last two decades, we remain cautious in over-interpreting the result of declining intergenerational status.

Overall, these results throw doubt on the claim that workers have lost subjective status over the last decades (Gidron \& Hall, 2017; Hochschild, 2016; Inglehart \& Norris, 2017), and they are also at odds with cross-sectional findings where respondents perceive their status as having fallen over time (Gest et al., 2018). Two reasons potentially explain this divergence. To begin with, nostalgic bias and the belief that the world was better in the past is deeply rooted in society (and skilfully exploited by the radical right), even if it lacks an empirical basis. To the extent that unskilled workers were already at the bottom of the status hierarchy in the 1980s, the possibility of further falling down the status ladder may have been limited. Moreover, the observed stability in subjective status is fully consistent with reference group theory and the idea that individuals compare their status to people similar to them (Evans et al., 1992). If members of the working class jointly travelled downwards in the socio-economic hierarchy, these shifts may not have left any marks on their subjective status.

What do our findings mean for the narrative that sees workers' falling social status as a prominent driver behind the rise of the radical right? The narrative's micro-foundations seem shaky because the working class reported similarly low levels of social status in the 1990s, 2000s and 2010s. Recent research suggests that perhaps the main change in social status over time has not taken place at the level of class, but at the level of place (Adler \& Ansell, 2020; Carreras et al., 2019; Jennings \& Stoker, 2018; Rodríguez-Pose, 2018). Rather than focusing on workers left behind, an alternative explanation may thus lie in communities left behind. As de-industrialization and globalization have concentrated opportunities and resources in a few thriving cities, residents in peripheral towns, declining industrial areas and rural regions may feel increasingly marginalized as a community. It may then be this collective loss of social status and broadly shared discontent at the geographical level that provides fertile ground for the radical right.

Another promising explanation of the rising radical right shifts the analytical lens from the demand-side of voters to the supply-side of parties. Over the last three decades, social democratic parties have intensified their courting of the salaried middle classes. As they moved towards the centre on economic issues, they reduced political conflict over the economy with conservative parties (Kriesi et al., 2008; Rennwald \& Evans, 2014). As a consequence, political differences over culture - notably migration and supra-national integration - have become much salient. The radical right has been successful in exploiting this growing cultural conflict in order to attract workers who felt orphaned by the social democratic move towards the centre 
(Betz \& Meret, 2012; Oesch \& Rennwald, 2018). Of course, these accounts remain speculative. Yet our results suggest that we may need another explanation for the radical right's rise than the status loss of the working class.

\section{Acknowledgments}

This paper was written within the National Centre of Competence in Research LIVES 'Overcoming vulnerability: Life course perspectives', financed by the Swiss National Science Foundation. We are grateful for the financial support. Earlier versions were presented at the universities of Geneva, Luxembourg, Zurich as well as the 2020 conferences of the ECSR and Swiss political science association. We greatly benefitted from the comments by Tarik Abou-Chadi, Louis Chauvel, Alessandro Di Nallo, Lea Elsässer, Geoffrey Evans, Thomas Kurer, Jonas Pontusson and David Weisstanner.

\section{Declaration of Conflicting Interests}

The author(s) declared no potential conflicts of interest with respect to the research, authorship, and/or publication of this article.

\section{Funding}

The author(s) disclosed receipt of the following financial support for the research, authorship, and/or publication of this article: This work was supported by the Schweizerischer Nationalfonds zur Förderung der Wissenschaftlichen Forschung grant number 51NF40-185901.

\section{ORCID iDs}

Daniel Oesch (1) https://orcid.org/0000-0003-1704-853X

Nathalie Vigna (1) https://orcid.org/0000-0001-9338-2703

\section{Supplementary Material}

Supplementary material for this article is available online.

\section{Notes}

1. A case in point is given by Veenhoven $(2008$, p. 53) who each year asked his incoming sociology students to vote on whether modernization over the last century had made society more or less livable. Year after year, a majority would state that it has made society less livable - although life expectancy doubled, literacy increased from below $20 \%$ to above $80 \%$ and income per capita grew many-fold (Piketty, 2019, p. 32).

2. A prominent example was Donald Trump's campaign slogan to 'make America great again' that directly appealed to a mythical golden past (Inglehart \& Norris, 2017, p. 16). 
3. The best illustration of this phenomenon is the extent to which incoming left governments in the 1990s shifted their appeal from the working to the middle class. A particularly clear case is the UK where the then Prime Minister Tony Blair invited Labour supporters to join his shift from 'the old establishment to a new, larger, more meritocratic middle class' (Guardian, 15. 1. 1999). Similarly, in 1997 Labour's deputy Prime Minister John Prescott allegedly remarked that 'we're all middle class now'.

4. 'Since social status is closely associated with the quality of a person's occupation, these developments [in technology and the economy] are likely to have depressed the social status of many workers' (Gidron \& Hall, 2017, p. 63).

5. Complete replication material for our empirical analysis can be found at Oesch and Vigna (2021).

6. These countries include Australia, Austria, Czech Republic, Russia, Slovak Republic and Slovenia.

7. The question wording is: 'Please think of your present job (or your last one if you don't have one now). If you compare this job with the job your father had when you were [14/15/16], would you say that the level or status of your job is (or was) ... much higher / higher / about equal / lower / much lower than your father's'.

8. For some countries and survey rounds, occupations were measured at a less detailed level, notably for Britain, Poland and the United States in 1987 as well as Britain and Sweden in 1992. From 2014 on, occupations were measured with ISCO-08 instead of ISCO-88. Supplementary Table W2 (web-appendix) provides detailed information and the Stata codes to define social classes in ISSP are available on one author's personal website: https://people.unil.ch/danieloesch/ scripts/

9. In our predictive margins plots, we show results that combine certain classes with certain education levels in order to avoid rare and atypical combinations such as being in the unskilled working class and having a university degree or being in the upper-middle class and not having any post-compulsory schooling.

10. In order to get rid of trendless fluctuation, these estimates and confidence intervals are again locally smoothened. For the exact estimates and confidence intervals, please see Supplementary Figure W4 in the web-appendix.

11. These estimates and confidence intervals are again locally smoothened. For the exact estimates and confidence intervals, please see Supplementary Figure W5 in the web-appendix.

\section{References}

Adler, D., \& Ansell, B. (2020). Housing and populism. West European Politics, 43(2), 344-365.

Adler, N. E., Epel, E. S., Castellazzo, G., \& Ickovics, J. R. (2000). Relationship of subjective and objective social status with psychological and physiological 
functioning: Preliminary data in healthy, white women. Health Psychology, 19(6), 586-592.

Antonucci, L., Horvath, L., Kutiyski, Y., \& Krouwel, A. (2017). The malaise of the squeezed middle: Challenging the narrative of the 'left behind' Brexiter. Competition \& Change, 21(3): 211-229.

Betz, H. G., \& Johnson, C. (2004). Against the current-stemming the tide: The nostalgic ideology of the contemporary radical populist right. Journal of Political Ideologies, 9(3), 311-327.

Betz, H. G., \& Meret, S. (2012). Right-wing populist parties and the working class vote: What have you done for us lately? In J. Rydgren (Ed.), Class politics and the radical right (pp. 107-121). Routledge.

Bornschier, S., \& Kriesi, H. (2013) The populist right, the working class, and the changing face of class politics. In J. Rydgren (Ed.), Class politics and the radical right (pp. 10-29). Routledge.

Burgoon, B., van Noort, S., Rooduijn, M., \& Underhill, G. (2018). Positional deprivation and support for radical right and radical left parties. Economic Policy, 34(97), 49-93.

Carella, L., \& Ford, R. (2020). The status stratification of radical right support: Reconsidering the occupational profile of UKIP's electorate. Electoral Studies, 67, advance access.

Carreras, M., Irepoglu Carreras, Y., \& Bowler, S. (2019). Long-term economic distress, cultural backlash, and support for Brexit. Comparative Political Studies, 52(9), 1396-1424.

Case, A., \& Deaton, A. (2015). Rising morbidity and mortality in midlife among white non-Hispanic Americans in the 21st century. Proceedings of the National Academy of Sciences, 112(49), 15078-15083.

Castel, R. (1999). Pourquoi la classe ouvrière a-t-elle perdu la partie? Actuel Marx, 26(2), 15-24.

Chan, T. W., \& Goldthorpe, J. H. (2004). Is there a status order in contemporary British society?: Evidence from the occupational structure of friendship. European Sociological Review, 20(5), 383-401.

Chan, T. W., Henderson, M., Sironi, M., \& Kawalerowicz, J. (2020). Understanding the social and cultural bases of Brexit. The British Journal of Sociology, 71(5), $830-851$.

Chetty, R., Grusky, D., Hell, M., Hendren, N., Manduca, R., \& Narang, J. (2017). The fading American dream: Trends in absolute income mobility since 1940. Science, 356(6336), 398-406.

Dwyer, R. E., \& Wright, E. O. (2019). Low-wage job growth, polarization, and the limits and opportunities of the service economy. RSF: The Russell Sage Foundation Journal of the Social Sciences, 5(4), 56-76.

Elchardus, M., \& Spruyt, B. (2016). Populism, persistent republicanism and declinism: An empirical analysis of populism as a thin ideology. Government and Opposition, 51(1), 111-133. 
Erikson, R., \& Goldthorpe, J. (1992). The constant flux: A study of class mobility in industrial societies. Clarendon Press.

Esping-Andersen, G. (1990). The three worlds of welfare capitalism. Princeton University Press.

Evans, M. D. R., \& Kelley, J. (2004). Subjective social location: Data from 21 nations. International Journal of Public Opinion Research, 16(1), 3-38.

Evans, M. D. R., Kelley, J., \& Kolosi, T. (1992). Images of class: Public perceptions in Hungary and Australia. American Sociological Review, 57(4), 461-482.

Ganzeboom, H. B. G., \& Treiman, D. J. (1996). Internationally comparable measures of occupational status for the 1988 international standard classification of occupations. Social Science Research, 25(3), 201-239.

Gautié, J., \& Schmitt, J. (Eds.). (2010). Low-wage work in the wealthy world. Russell Sage Foundation.

Gest, J. (2016). The new minority: White working class politics in an age of immigration and inequality. Oxford University Press.

Gest, J., Reny, T., \& Mayer, J. (2018). Roots of the radical right: Nostalgic deprivation in the United States and Britain. Comparative Political Studies, 51(13), 1694-1719.

Gidron, N., \& Hall, P. A. (2017) The politics of social status: Economic and cultural roots of the populist right. The British Journal of Sociology, 68(S1), S57-S84.

Gidron, N., \& Hall, P. A. (2019) Populism as a problem of social integration. Comparative Political Studes, 53(7), 1027-1059.

Goos, M., \& Manning, A. (2007) Lousy and lovely jobs: The rising polarization of work in Britain. Review of Economics and Statistics, 89(1), 118-133.

Hall, P. A., \& Lamont, M. (2013) Introduction. P. A. Hall \& M. Lamont (Eds.), Social resilience in the neoliberal era (pp. 1-34). Cambridge University Press.

Hobolt, S. B. (2016). The Brexit vote: A divided nation, a divided continent. Journal of European Public Policy, 23(9), 1259-1277.

Hochschild, A. R. (2016) Strangers in their own land. New Press.

Im, Z. J., Mayer, N., Palier, B., \& Rovny, J. (2019). The "losers of automation": A reservoir of votes for the radical right? Research \& Politics, 6(1), 1-7.

Inglehart, R. \& Norris, P. (2017) Trump and the populist authoritarian parties: The silent revolution in reverse. Perspectives on Politics, 15(2), 443-454.

Jennings, W., \& Stoker, G. (2018). The divergent dynamics of cities and towns: Geographical polarisation after Brexit. The Political Quarterly, 90(2), 155-166.

Kelley, J., \& Evans, M. D. R. (1995). Class and class conflict in six western nations. American Sociological Review, 60(2), 157-178.

Kriesi, H., Grande, E., Lachat, R., Dolezal, M., Bornschier, S., \& Frey, T. (2008). West European politics in the age of Globalization. Cambridge University Press.

Kurer, T., \& Palier, B. (2019). Shrinking and shouting: The political revolt of the declining middle in times of employment polarization. Research \& Politics, 6(1), 205316801983116. 
Lindemann, K., \& Saar, E. (2014). Contextual effects on subjective social position: Evidence from European countries. International Journal of Comparative Sociology, 55(1), 3-23.

McPherson, M., Smith-Lovin, L., \& Cook, J. M. (2001). Birds of a feather: Homophily in social networks. Annual Review of Sociology, 27(1), 415-444.

Merton, R. K., \& Kitt, A. S. (1950). Contributions to the theory of reference group behavior. In R. K. Merton \& P. F. Lazarsfeld (Eds.), Continuities in social research: Studies in the scope and method of the American soldier (pp. 40-105). Free Press.

Nolan, B., \& Thewissen, S. (2018). The evolution of living standards for middle and lower income households in OECD countries. In B. Nolan (Ed.), Generating prosperity for working families in affluent countries. Oxford University Press.

Nolan, B., \& Thewissen, S. (2020). Inequality and real income growth for middle- and low-income households across rich countries in recent decades. In J. G. Rodríguez \& J. A. Bishop (Eds.), Inequality, redistribution and mobility, Emerald Publishing, pp. 1-28.

Oesch, D. (2006). Redrawing the class map: Stratification and institutions in Britain, Germany, Sweden and Switzerland. Palgrave Macmillan.

Oesch, D., \& Piccitto, G. (2019). The polarization myth: Occupational upgrading in Germany, Spain, Sweden, and the UK, 1992-2015. Work and Occupations, 46(4), 441-469.

Oesch, D., \& Rennwald, L. (2018). Electoral competition in Europe's new tripolar political space: Class voting for the left, centre-right and radical right. European Journal of Political Research, 57(2), 783-807.

Oesch, D., \& Vigna, N. (2021). Replication data for: A decline in the social status of the working class? Conflicting evidence for 8 Western countries 1987-2017, comparative political studies. Harvard Dataverse. Retrieved from: https://oi.org/10. 7910/DVN/N3DG91.

Piketty, T. (2013). Le capital au XXIe siècle. Seuil.

Piketty, T. (2019). Capital et idéologie. Seuil.

Rennwald, L., \& Evans, G. (2014). When supply creates demand: Social democratic party strategies and the evolution of class voting. West European Politics, 37(5), 1108-1135.

Ridgeway, C. L. (2014). Why status matters for inequality. American Sociological Review, 79(1): 1-16.

Rodríguez-Pose, A. (2018). The revenge of the places that don't matter (and what to do about it). Cambridge Journal of Regions, Economy and Society, 11(1), 189-209.

Rydgren, J. (2013). Class politics and the radical right. Routledge.

Schneider, S. M. (2019). Why income inequality is dissatisfying-perceptions of social status and the inequality-satisfaction link in Europe. European Sociological Review, 35(3), 409-430.

Schwartz, O. (2009). Vivons-nous encore dans une société de classes? Trois remarques sur la société française contemporaine. La Vie des Idées, 22, 1-7. 
Singh-Manoux, A., Adler, N. E., \& Marmot, M. G. (2003). Subjective social status: Its determinants and its association with measures of ill-health in the Whitehall II study. Social Science \& Medicine, 56(6), 1321-1333.

Smith, T. (1986). Internationally comparable measurement of subjective social class. Presentation to the April 1986 Planning Meeting of the International Social Survey Programme, Mannheim, Germany.

Stiglitz, J. (2015). The great divide. Penguin.

Taggart, P. (2002). Populism and the pathology of representative politics. In Y. Mény \& Y. Surrel (Eds.), Democracies and the populist challenge (pp. 62-80). Palgrave.

van Noord, J., Spruyt, B., Kuppens, T., \& Spears, R. (2019). Education-based status in comparative perspective: The legitimization of education as a basis for social stratification. Social Forces, 98(2), 649-676.

Veenhoven, R. (2008). Sociological theories of subjective well-being. In Eid, M. \& Larsen, R. (Eds.), The science of subjective well-being: A tribute to Ed Diener (pp. 44-61) Guilford Publications.

Weber, M., (2005 [1922]). Wirtschaft und Gesellschaft. Zweitausendeins.

Wright, E. O., \& Dwyer, R. (2003). The patterns of job expansions in the USA: A comparison of the 1960s and 1990s. Socio-Economic Review, 1(1), 289-325. 